\title{
Effect of the combined use of $\beta$-amylase and pullulanase on the carbohydrate composition of maltose syrups
}

\author{
Nataliia Sabadash ${ }^{1}$, Olena Hrabovska ${ }^{2}$, Igor Fesych ${ }^{1}$, \\ Alina Avramenko ${ }^{1}$, Anastasiia Serhiienko ${ }^{1}$
}

\author{
1 - National University of Food Technologies, Kyiv, Ukraine \\ 2 - Kyiv National University of Trade and Economics, Kyiv, Ukraine
}

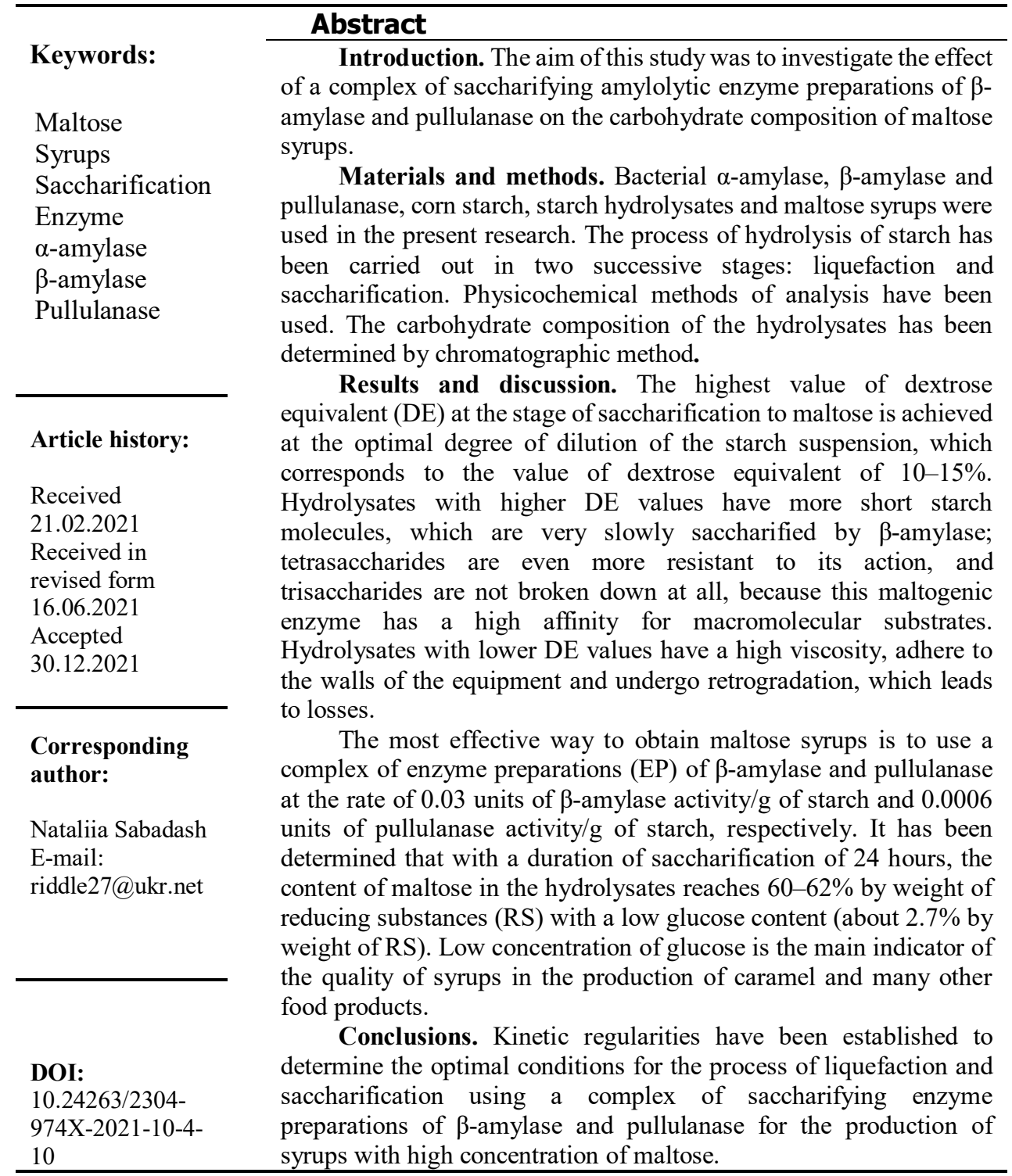




\section{Introduction}

The trend in the application of enzymes in the food industry is a relevant modern area of research. Microbial enzymes have long been used in food production, but every year they find new areas of application (Ivanov et al., 2021). Enzymatic conversion of starch to obtain syrups with a high content of maltose (more than $50 \%$ by weight of reducing sugars) are widely used for the production of ice cream, marmalade, jams, juices, beverages, beer, as well as to replace sugar in the production of lollipop caramel. High resistance to spontaneous crystallization, lower viscosity and hygroscopicity compared to glucose syrups (dextrose equivalent $38-42 \%$ ) characterizes these syrups. In addition, they contain a large amount of fermentable saccharides (Baks et al., 2008; Souza et al., 2019).

In the production of maltose syrups, it is important to transfer starch grains in suspension to a soluble state by temperature gelatinization in the presence of a catalyst. Gelatinized starch responds to the action of amylolytic enzymes much faster than the native one (Porras et al., 2018; Souza et al., 2019). To achieve minimum starch losses and obtain a syrup with good filtration properties, it is necessary to fully gelatinize all starch grains, including small ones. The gelatinization temperature of small starch grains is $120-140{ }^{\circ} \mathrm{C}$ (Souza et al., 2019). The process of enzymatic conversion of starch is carried out in two stages: liquefaction and saccharification. In the process of gelatinization, the viscosity increases significantly, which makes it difficult to carry out the liquefaction process. It is also necessary to prepare the substrate for saccharification. The maltogenic enzyme $\beta$-amylase, like other saccharifying enzymes, cannot effectively catalyze the hydrolysis of gelatinized starch due to its high viscosity. $\beta$-amylase is capable of cleaving the maltose molecule only from the non-reducing edge formed at the site of the $\alpha-1,4$-glucoside bond rupture (Porras et al., 2018; Souza et al., 2019). Therefore, in order to reduce the viscosity and avoid the phenomenon of retrogradation, it is necessary that the gelatinization of starch will be accompanied by its liquefaction. In the obtained low viscosity hydrolyzate it is easier to further break the starch molecule for final products of saccharification.

The degree of liquefaction of starch has a significant effect on the quality of maltose hydrolysates after saccharification. It is known (Lin et al., 2013; Radovanovic et al., 2018; Saini et al., 2017) that short starch molecules are attacked by the enzyme $\beta$-amylase very slowly, tetrasaccharides are even more resistant to its action, and trisaccharides are not broken down at all because this maltogenic enzyme shows a high affinity for high molecular weight substrates. Therefore, for maltose syrups to be obtained, in the saccharification stage it is desirable to use hydrolyzed starch with the lowest dextrose equivalent after liquefaction and a minimum amount of glucose. However, such a hydrolysate has a high viscosity (more than $2 \mathrm{~Pa} \cdot \mathrm{s}$ ) and adheres to the walls of equipment and pipelines (Gebremariam et al., 2013). Therefore, it is necessary to establish the optimal value of DE hydrolysates after enzymatic liquefaction for effective saccharification of starch hydrolysates to maltose.

It has been shown (Porras et al., 2018) that optimal parameters for the liquefaction process are: the concentration of the corn starch suspension - 30\%; using of thermostable bacterial enzyme preparation of $\alpha$-amylase Alphasin T7L -4 units of amylolytic activity per gram of dry matter of starch. The degree of liquefaction of the starch suspension should correspond to the DE value of $18-20 \%$. However, these studies focused on the effect of the degree of starch liquefaction on the subsequent saccharification of hydrolysates to glucose, where glucoamylase was used as a saccharifying enzyme (Trisnaputri et al., 2018; Yadav et al., 2017). To obtain syrups with a high maltose content at the saccharification stage, we used maltogenic enzyme preparations. In order to clarify the results of previous studies, it was necessary to establish the effect of the degree of starch liquefaction on the kinetics of further 
saccharification of hydrolysates to maltose. As it is known (Baks et al., 2008), for the production of maltose syrups with an amount of maltose of about $50 \%$, a preparation of the maltogenic enzyme $\beta$-amylase is used as a biocatalyst for the hydrolysis reaction. The subsequent accumulation of maltose is prevented by $\beta$-limit dextrins, which are formed in an amount of about $23 \%$ under the action of $\beta$-amylase on rarefied starch (Baks et al., 2008; Lin et al., 2013). To make the substrate more accessible for the action of $\beta$-amylase, it is necessary to use an enzyme that breaks the branches in the amylopectin chains that are not affected by the enzyme preparation of $\beta$-amylase (EP 0294093 A2).

A promising direction for expanding the range of maltose syrups is the search for new enzyme preparations and their combinations to increase the accumulation of maltose in hydrolysates. One of these enzyme is a pullulanase preparation (amylo-1,6-glucosidase), which hydrolyzes $\alpha$-1,6-glucosidic bonds at the branch points of the starch molecule. The ability to break $\alpha-1,6$-bonds is significantly increased if they are surrounded on all sides by $\alpha-1,4$-bonds. As a result of its action, linear dextrins are formed with non-reducing residues of molecules that can be hydrolyzed by the enzyme preparation of $\beta$-amylase. The use of pullulanase in the composition with $\beta$-amylase will change the carbohydrate composition of the hydrolysates in the direction of the accumulation of maltose (Gangadharan et al., 2009; Rittenauer et al., 2021; Souza et al., 2019).

The aim of the work was to determine the effect of a complex of saccharifying amylolytic enzyme preparations of $\beta$-amylase and pullulanase on the carbohydrate composition of maltose syrups.

\section{Materials and methods}

\section{Materials}

For the purposes of our research, corn starch and maltose hydrolysates of various degrees of saccharification were used.

\section{Chemical reagents and enzymes}

Hydrochloric acid (1 $\mathrm{N}$ concentration).

Amylolytic enzyme preparations: (1) Thermostable bacterial $\alpha$-amylase Alphasin T7L from Genencor International B.V. (A Danisco Division), activity - 1240 units of $\alpha$-amylase activity/g of enzyme preparation (units AA/g of EP), $\mathrm{pH} 5.5-7.0$, optimal $\mathrm{pH} 5.8$, temperature $60-110{ }^{\circ} \mathrm{C}$, optimal temperature $108{ }^{\circ} \mathrm{C}$ (retains activity for 1 hour at a temperature of $105-108^{\circ} \mathrm{C}$ ); (2) $\beta$-amylase Optimalt BBA from Genencor International B.V. (A Danisco Division), activity - 69 units of $\beta$-amylase (saccharifying) activity/g of enzyme preparation (units $\mathrm{SA} / \mathrm{g}$ of EP), $\mathrm{pH} 4.8-6.0$, optimum $\mathrm{pH} 5.2-5.5$, temperature $55-60{ }^{\circ} \mathrm{C}$, optimum temperature $57^{\circ} \mathrm{C}$ (retains activity for 6 hours at a temperature of $60-63{ }^{\circ} \mathrm{C}$; inactivated in 15 minutes at a temperature of $75^{\circ} \mathrm{C}$ ); (3) Pullulanase Gamylozym KPU-L Gammazym (Germany), activity - 0.8 units of pullulanase activity/g of enzyme preparation (units $\mathrm{PA} / \mathrm{g}$ of $\mathrm{EP}$ ), $\mathrm{pH} 4.3-7.5$, optimal $\mathrm{pH} 5.0-6.3$, temperature $45-68{ }^{\circ} \mathrm{C}$, optimum temperature $55^{\circ} \mathrm{C}$ (inactivated in 10 minutes at a temperature of $95^{\circ} \mathrm{C}$ ). 


\section{Research methods}

The dry substances (DS) content, \% by weight, in the hydrolysates and the finished product was determined refractometrically, while in the raw material it was determined by drying to constant weight (Nielsen, 2010).

The $\mathrm{pH}$ was determined potentiometrically (Manso et al., 2017).

Liquefaction of the starch suspension was performed under the influence of an ultrahigh frequency electromagnetic field or in a special thermostat under a slight excess pressure at a temperature of $110{ }^{\circ} \mathrm{C}$ (Nawaz et al., 2020) [JPH06102032B2].

The total content of reducing substances (\% by weight of DS) - dextrose equivalent (DE) - was determined by the iodometric method of Wilshtetter and Schudl (Nielsen, 2010).

\section{Activity of enzyme preparations}

Amylolytic activity of bacterial $\alpha$-amylase. Determination of amylolytic activity of bacterial $\alpha$-amylase was performed by colorimetric method. The method is based on the hydrolysis of starch by enzymes of the amylolytic complex to dextrins of different molecular weight (Iskakova et al., 2017).

Amylolytic activity of $\alpha$-amylase (AA) characterizes the ability of amylolytic enzymes to catalyze the hydrolysis of starch to dextrins of different molecular weight and is expressed by the number of unit's activity of these enzymes in $1 \mathrm{~g}$ of the enzyme preparation.

One unit of amylolytic activity is the ability of the enzyme at certain values of temperature, $\mathrm{pH}$ and time of action to catalyze the hydrolysis of $1 \mathrm{~g}$ of starch to dextrins of different molecular weight.

Amylolytic activity of thermostable EP was determined at a temperature of $50{ }^{\circ} \mathrm{C}$. Hydrolysis of starch under these conditions occurred at $25-30 \%$.

Saccharification activity of $\boldsymbol{\beta}$-amylase. Determination of the saccharification activity of $\beta$-amylase (SA) was performed by the polarimetric method. The polarimetric method is based on determining the rate of the enzymatic reaction of starch hydrolysis, which is set by decreasing the angle of rotation of the polarization plane. This reduction is due to the formation of low molecular weight carbohydrates due to the action of enzymes on starch (Manisha et al., 2016).

One unit of saccharification activity is defined as the amount of enzyme which in strictly defined conditions $\left(\mathrm{pH} 4.7-4.9\right.$, temperature $50{ }^{\circ} \mathrm{C}$, reaction time $30 \mathrm{~min}$ ) catalyzes the hydrolysis of $1 \mathrm{~g}$ of starch (which is $25-30 \%$ ) to low molecular weight carbohydrates.

To determine the saccharification activity, $1 \%$ of the starch solution is hydrolyzed and the polarization of the reaction mixture before and after the action of the enzyme is determined, thus establishing a decrease in the angle of rotation of the substrate polarization plane $(\Delta \mathrm{P})$ under the action of enzymes.

Pullulanase activity. Pullulanase activity (PA) is determined by the amount of reducing carbohydrates formed from the substrate (phosphodestrin) during the enzymatic reaction. The amount of reducing substances is determined by iodometric method (Meile et al., 2018). The number of units of activity of the enzyme taken for analysis is calculated according to the number of reducing carbohydrates that have been formed.

One unit of pullulanase activity is the amount of enzyme which in defined conditions (temperature $30{ }^{\circ} \mathrm{C}, \mathrm{pH} 4.7-4.9$, reaction time $60 \mathrm{~min}$ ) catalyzes $30 \%$ hydrolysis of $\alpha-1,6$ glucoside bonds in $1 \mathrm{~g}$ of phosphodiesters to reducing carbohydrates. 
Carbohydrate composition of hydrolysates. The carbohydrate composition of the hydrolysates was determined by chromatographic analysis on a liquid chromatograph «Agilent 1100» (manufacturer - Agilent, USA). Concentration of working solutions was 3$5 \%$ DS; water served as eluent; eluent flow rate was $0.5 \mathrm{ml} / \mathrm{min}$. Analytical columns were SupelCogel Ca (manufacturer - SupelCo, USA) and HPH 87C (manufacturer - Bio-Rad) size $300 \times 7.8 \mathrm{~mm}$ for the separation of carbohydrates and alcohols. Adsorbent analytical column (filler, gel filtration resin) was styrene-divinylbenzene polymer in grafted calcium form with a particle diameter of $5 \mu \mathrm{m}$.

Sample injection was performed using a syringe and injector with a dosing loop of 10 $\mu 1$. The column was thermostated in a thermostat maintaining a column temperature of $80^{\circ} \mathrm{C}$ $\left( \pm 0.1^{\circ} \mathrm{C}\right)$. To protect the column, a safety cartridge was used, which, in addition to cleaning the sample from impurities, also provides its demineralization from salts (primarily from sodium chloride).

\section{Experiment 1. Determination of the optimal degree of starch suspension liquefaction with bacterial $\alpha$-amylase for further saccharification of hydrolysates to maltose}

To carry out the liquefaction in one-step, we used a thermostable enzyme preparation of bacterial $\alpha$-amylase as a biocatalyst, which does not lose activity at high temperatures required for gelatinization of small starch grains (Gebremariam et al., 2013; Lin et al., 2013). This will significantly increase the rate of starch liquefaction. From a wide range of enzyme preparations of $\alpha$-amylase of bacterial origin, Alphasin T7L was selected, which is a thermostable enzyme preparation with the highest optimal temperature $108^{\circ} \mathrm{C}$, and the $\mathrm{pH}$ of 5.5-7.0.

The method of single-stage hydrolysis, which allows obtaining a hydrolyzate with residues of starch molecules of average size and has a number of advantages, was used. The use of thermostable enzyme preparation allows one not to lower the temperature below 95 ${ }^{\circ} \mathrm{C}$, which prevents retrogradation. This method of liquefaction also enables one to reduce the dosage of the enzyme preparation.

During the study, a suspension of corn starch with a mass fraction of $30 \%$ DS was prepared. For enzymatic liquefaction, the enzyme preparation of thermostable bacterial $\alpha$ amylase Alphasin T7L was used, which was added in the recommended amount of 4 units AA/g DS of corn starch (Lin et al., 2013). To detect the maximum activity of the enzyme preparation, the optimal $\mathrm{pH}$ value is 5.8 , which was achieved by adding $1 \mathrm{~N} \mathrm{HCl}$ solution to the substrate. Thinning of the suspension was carried out in one stage under a slight excess pressure in a special thermostat at a temperature of $110^{\circ} \mathrm{C}$ to different values of $\mathrm{DE} 10,15$, $20,25 \%$.

For saccharification, the mixture of $\beta$-amylase and pullulanase enzyme preparations was added to the obtained liquefied suspension in the amount of 0.12 units of saccharifying activity per gram of dry matter of starch (units SA/g) and 0.003 units of pullulanase activity per gram of dry matter of starch (units PA/g). Saccharifying lasted for 48 hours, during which samples were taken and the dextrose equivalent (DE) was determined.

\section{Experiment 2. Study of saccharification kinetics depending on the dosage of saccharifying enzyme preparations of $\beta$-amylase and pullulanase}

During the study, a suspension of corn starch with a dry substance content of $30 \%$ was prepared. The enzymatic liquefaction was performed as described in experiment 1 . 
The liquefaction time was 13 minutes before reaching the value of DE hydrolyzate in the range of $10-15 \%$, which, according to experiment 1 , was determined as optimal for further saccharification.

After liquefaction, the hydrolyzate was cooled to a temperature of $57^{\circ} \mathrm{C}$ and the $\mathrm{pH}$ was adjusted to $5.2-5.5$ by adding a solution of $1 \mathrm{~N} \mathrm{HCl}$. These parameters are optimal for the action of the enzyme preparation $\beta$-amylase Optimalt BBA and are within the optimum for pullulanase Gamylozym KPU-L (optimum effect at $\mathrm{pH}$ is 5.0-7.5 and temperature 45-68 ${ }^{\circ} \mathrm{C}$ ), which also does not contradict the optimal parameters of $\beta$-amylase. Therefore, this enzyme preparation of pullulanase was chosen.

The saccharification process was performed by simultaneously adding to the substrate enzyme preparations of $\beta$-amylase and pullulanase in different amounts. Dosing of $\beta$-amylase was performed in all samples at the rate of 0.03 units of saccharifying activity per $g$ of dry substances (units SA/g DS) of starch (Sabadash et al., 2015). Pullulanase was dosed in amounts of $0.00005 ; 0.0002 ; 0.0004 ; 0.0006 ; 0.0008 ; 0.005 ; 0.01 ; 0.02 ; 0.03$ units of pullulanase activity per g of dry substances (units PA/g DS) of starch (Figs. 3, 4). Pullulanase was not added to the control sample. Enzymatic saccharification of hydrolysates was performed for $48 \mathrm{~h}$ in an EL-20R thermostat at a temperature of $57^{\circ} \mathrm{C}$ with constant stirring. Samples of hydrolysates taken in the saccharification process at 1, 4, 8, 12, 16, 20, 24 and 48 hours were kept in a boiling water bath for 15 minutes to inactivate the enzyme. In chilled samples, the DE index was determined by the iodometric method of Wilshtetter and Schudl.

\section{Results and discussion}

Experiment 1. Influence of the degree of liquefaction of starch on the kinetics of subsequent saccharification of hydrolysates by enzymatic preparations of $\beta$-amylase and pullulanase

The kinetics of starch saccharification to maltose by a complex of $\beta$-amylase and pullulanase enzyme preparations was studied. The effect of $\mathrm{DE}$ after liquefaction on the saccharification of hydrolysates to maltose was determined. The duration of the experiment was 48 hours before reaching the maximum content of maltose in the hydrolyzate. The graphs of the kinetics of the saccharification process for the first twelve hours of the experiment for different values of DE, which were achieved during liquefaction, are presented in Figure 1. Figure 2 shows the effect of the degree of liquefaction on the glucose equivalent after 24 and 48 hours of saccharification. 


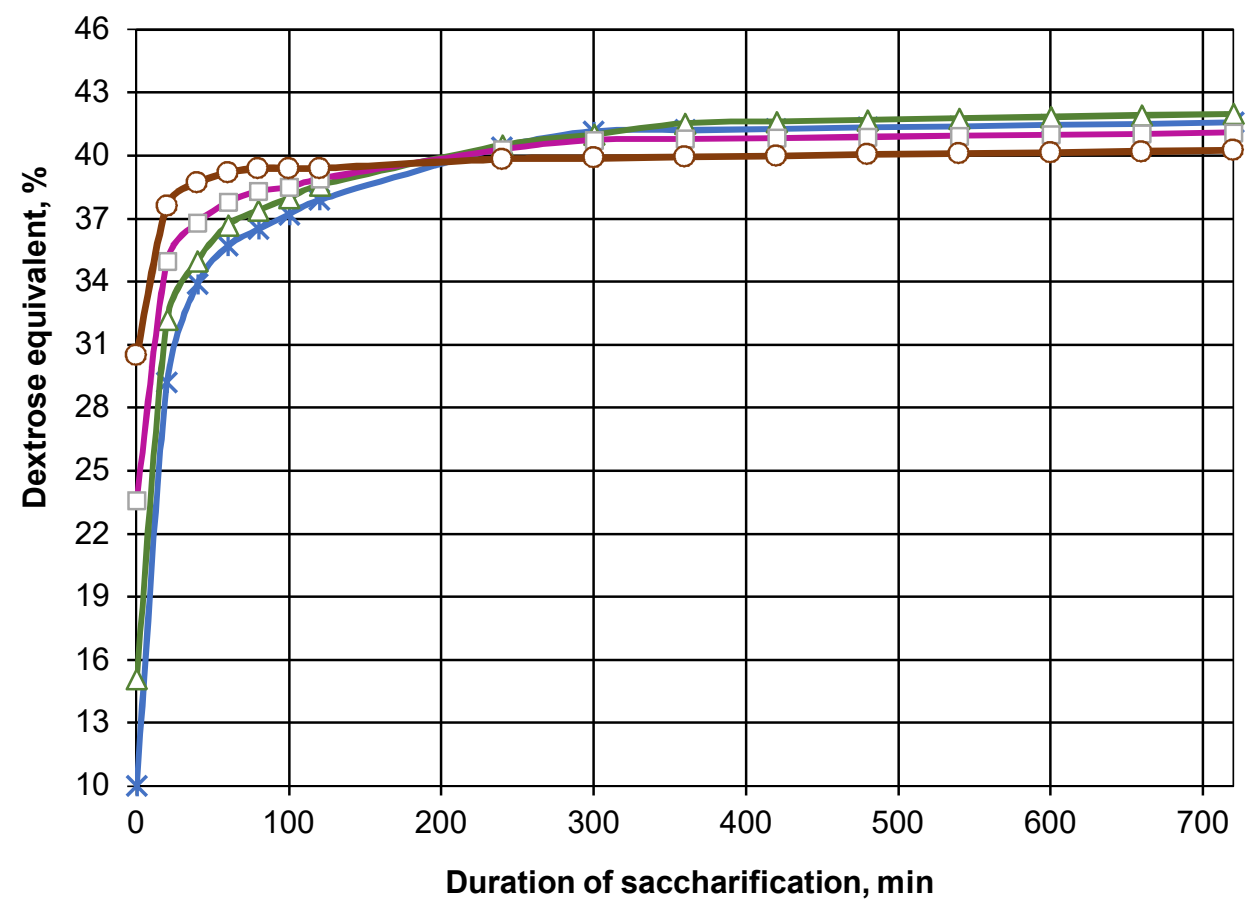

$\because$ DE 10\% $\longrightarrow$ DE 15\% —DE 20\% —DE 25\%

Figure 1. Kinetics of the process of enzymatic saccharification of liquefied starch hydrolysates at different DE values after liquefaction: $10 ; 15 ; 20 ; 25 \%$

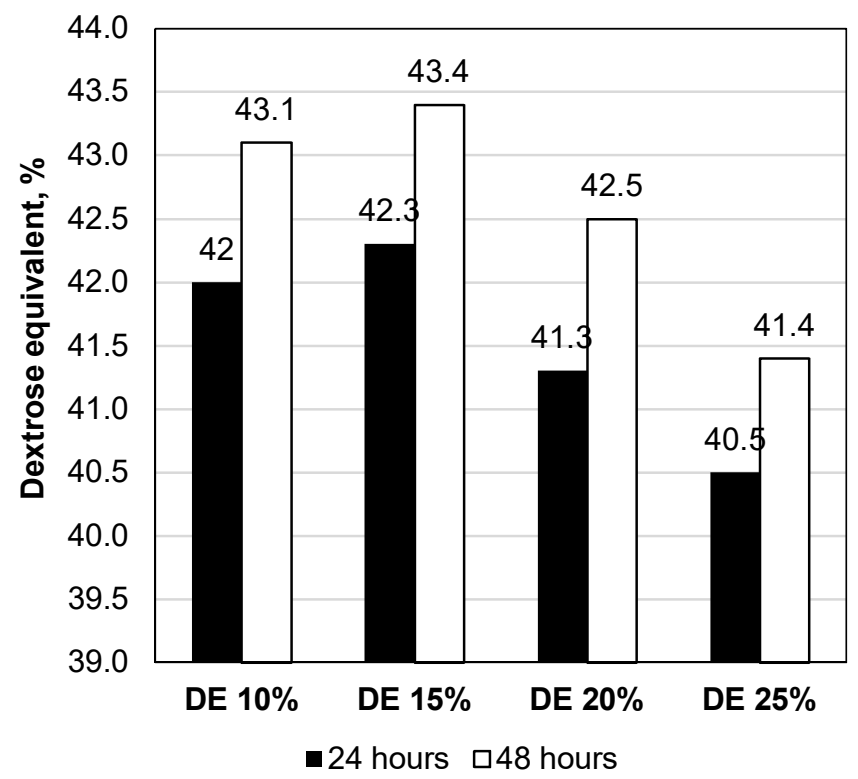

Figure 2. Effect of the degree of liquefaction on glucose equivalent after saccharification after 24 and 48 hours 
At the beginning of the saccharification process, the increase in DE for all four samples occurs at different speeds, but after 3-4 hours from the beginning of the process the values of DE almost coincide (Figure 1). Continuation of the saccharification process leads to a gradual increase in the $\mathrm{DE}$ in the hydrolysates that had lower DE values after liquefaction (DE $10 ; 15 \%)$. That is, with a decrease in the degree of polymerization of hydrolyzate molecules after liquefaction (DE 20;25\%) there is a decrease in the rate of their cleavage during saccharification to maltose, because $\beta$-amylase has an affinity for high molecular weight substrate. In addition, the ability of pullulanase to cleave $\alpha-1,6$-bonds is significantly increased if they are surrounded on all sides by $\alpha$-1,4-bonds, which is possible with a low degree of liquefaction (DE 10; 15\%). Low DE after liquefaction (DE 10;15\%) enables the formation of linear dextrins that are hydrolyzed by the maltogenic enzyme preparation of $\beta$ amylase (Souza et al., 2019; Gangadharan et al., 2009; Rittenauer et al., 2021), which allows to obtain hydrolysates with higher DE after saccharification (Figure 2).

However, samples with low DE values after liquefaction $(10 \%)$ have a high viscosity of the suspension (Baks et al., 2008), which impairs its contact with the enzyme (Rittenauer et al., 2021) and complicates the saccharification process (Rittenauer et al., 2021). Also, the saccharification of high-molecular substrate (GE $10 \%$ ) is complicated by its tendency to retrogradation (Souza et al., 2019).

For saccharification in the production of maltose syrups, it is desirable to use a liquefied hydrolyzate containing cleavage products of medium size. The degree of pre-dilution of starch has a significant effect on the liquefaction of hydrolysates to maltose, even minor changes in carbohydrate composition after liquefaction could slow down the saccharification process. Due to the presence of unwanted by-substances in the hydrolyzate, the quality of final maltose syrups deteriorates, their yield and maltose content decrease, as it is impossible to achieve sufficient complete saccharification of starch (Baks et al., 2008; Rittenauer et al., 2021). Therefore, the enzymatic liquefaction of the suspension should be carried out to the value of GE hydrolyzate $15 \%$ (Figure 2), which is optimal for further saccharification to maltose. The viscosity of such hydrolysates is significantly reduced (Souza et al., 2019), and the degree of polymerization of polysaccharide molecules remains high (Rittenauer et al., 2021).

\section{Experiment 2. Study of the saccharification process depending on the dosage of enzyme preparations of $\beta$-amylase and pullulanase}

According to experimental data, kinetic curves of the process of saccharification of liquefied starch with a complex of enzyme preparations of $\beta$-amylase and pullulanase depending on their dosage were constructed (Figure 3). Pullulanase was not added to the control sample. The research results are presented in Figures 3 and 4. The carbohydrate composition, in particular the maltose content in the obtained hydrolysates, was determined by the method of chromatographic analysis on a liquid chromatograph «Agilent 1100» (Figure 5). 


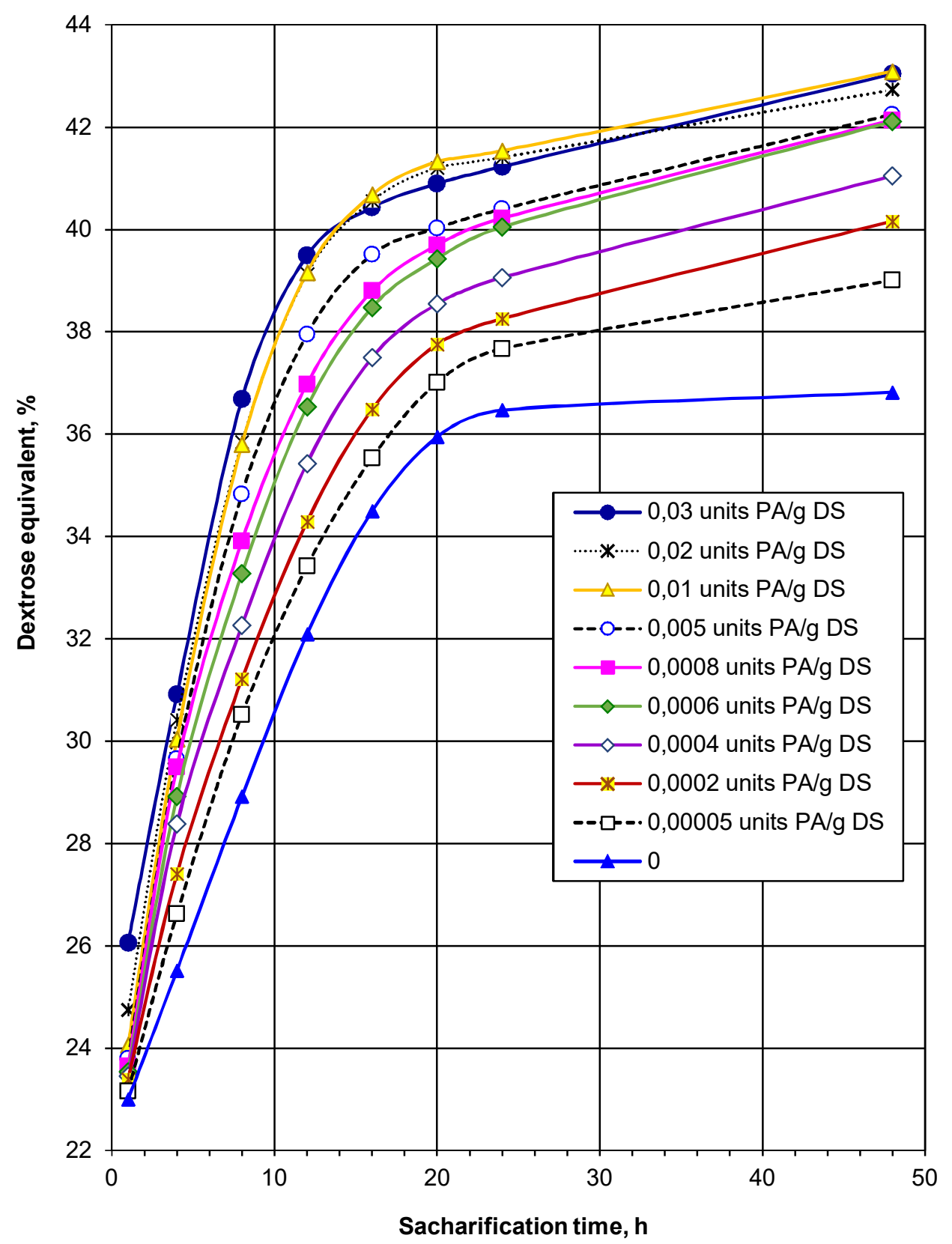

Figure 3. Kinetics of enzymatic saccharification of liquefied starch under the conditions of using a complex of enzymatic preparations of $\beta$-amylase (in the amount of 0.03 units SA/g DS of starch) and different amounts of pullulanase 


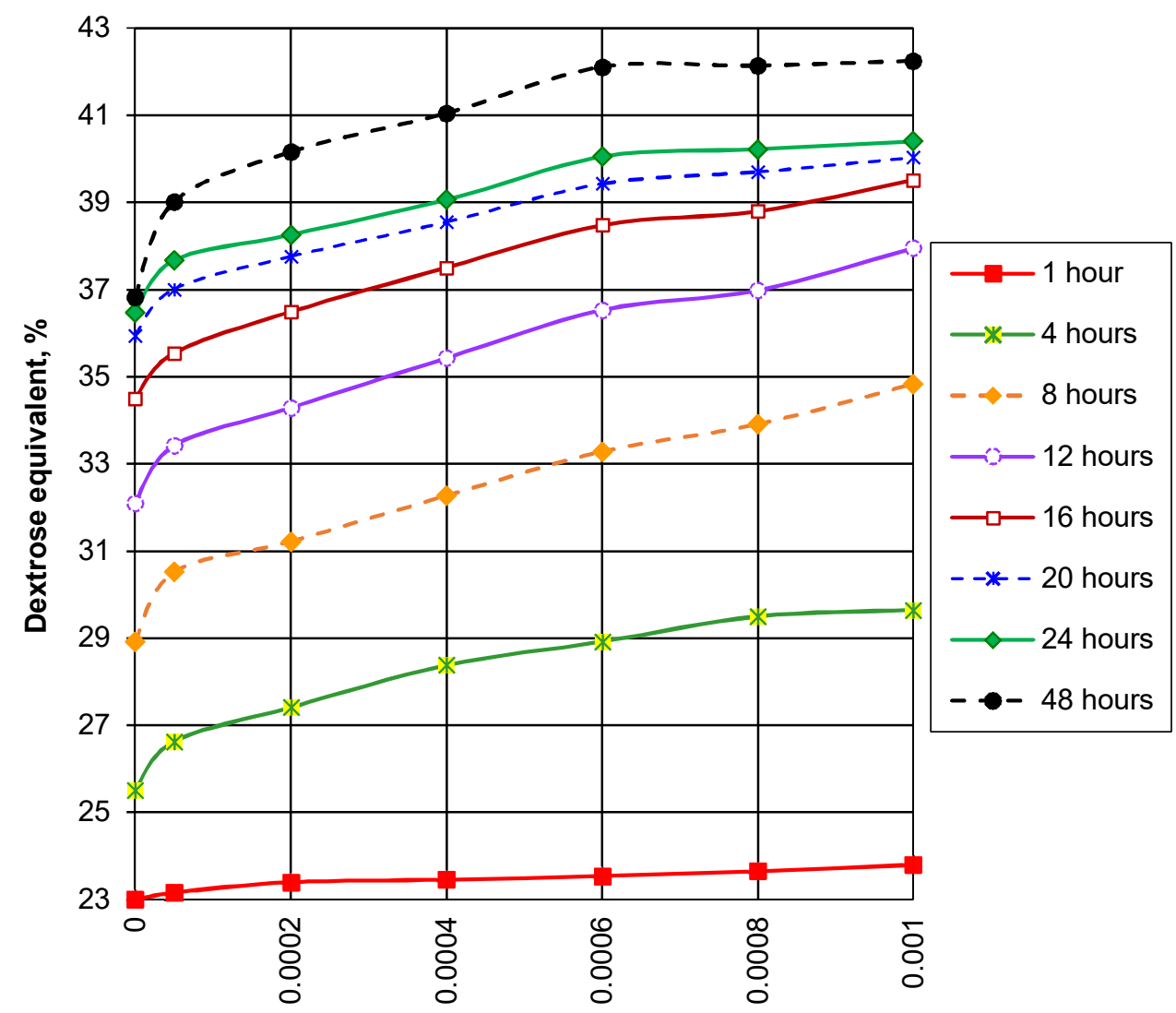

Amount of pullulanase, units PA/g DS of starch

Figure 4. Dependence of the glucose equivalent of maltose syrup on the amount of enzyme preparation of pullulanase, the amount of added $\beta$-amylase 0.03 units SA/g DS of starch

The data obtained (Figures 3,4) show that the use of a complex of enzyme preparations of $\beta$-amylase and pullulanase improves the saccharification process, compared with the use of $\beta$-amylase only (control sample), and leads to increased maltose content in hydrolysates. This is due to the hydrolysis of dextrins to maltose (Table 1) (Lin et al., 2013). Depending on the consumption of pullulanase, DE increases by $1-5 \%$ in 24 hours of saccharification (Figure 4). During the second day, there is an increase in DE by another $1.3-2 \%$, which does not happen in the control sample (Figure 4). It is most effective to use a complex of enzyme preparations of $\beta$-amylase and pullulanase at the rate of $0.03 \mathrm{SA} / \mathrm{g}$ and $0.0006 \mathrm{PA} / \mathrm{g} \mathrm{DS}$ of starch, respectively. At the same time, after 24 hours of saccharification a DE value of $40 \%$ can be achieved. It is optimal to carry out the saccharification process for 24 hours.

Table 1 shows the results of chromatographic studies of starch hydrolyzate obtained at the optimal dosage of $\beta$-amylase (control sample) and at the optimal dosage of the complex of enzyme preparations of $\beta$-amylase and pullulanase after 24 hours of saccharification. 
Table 1

Results of chromatographic studies of starch hydrolysate obtained after 24 hours of saccharification

\begin{tabular}{|l|c|c|}
\hline $\begin{array}{l}\text { Carbohydrate } \\
\text { composition of } \\
\text { hydrolysates }\end{array}$ & $\begin{array}{c}\text { Saccharification with } \\
\boldsymbol{\beta} \text {-amylase (at the } \\
\text { rate of } \mathbf{0 . 0 3} \text { units } \\
\text { SA/g DS of starch) } \\
\text { (control sample), } \\
\text { \% by weight of RS }\end{array}$ & $\begin{array}{c}\text { Saccharification with a complex of } \\
\text { enzymatic preparations of } \boldsymbol{\beta} \text {-amylase } \\
\text { (at the rate of } \mathbf{0 . 0 3} \text { units SA/g DS of } \\
\text { starch) and pullulanase (at the rate of } \\
\mathbf{0 . 0 0 0 6} \text { units PA/g DS of starch) } \\
\text { \% by weight of RS }\end{array}$ \\
\hline Glucose & 2.5 & 2.7 \\
\hline Maltose & 50.8 & 58.6 \\
\hline Trisaccharides & 23.5 & 29.4 \\
\hline Tetrasaccharides & 1.8 & 1.5 \\
\hline DP5 and more & 21.4 & 7.8 \\
\hline
\end{tabular}

According to the results of chromatographic analysis, the carbohydrate composition of maltose syrups was calculated, which is presented in the diagram (Figure 5).

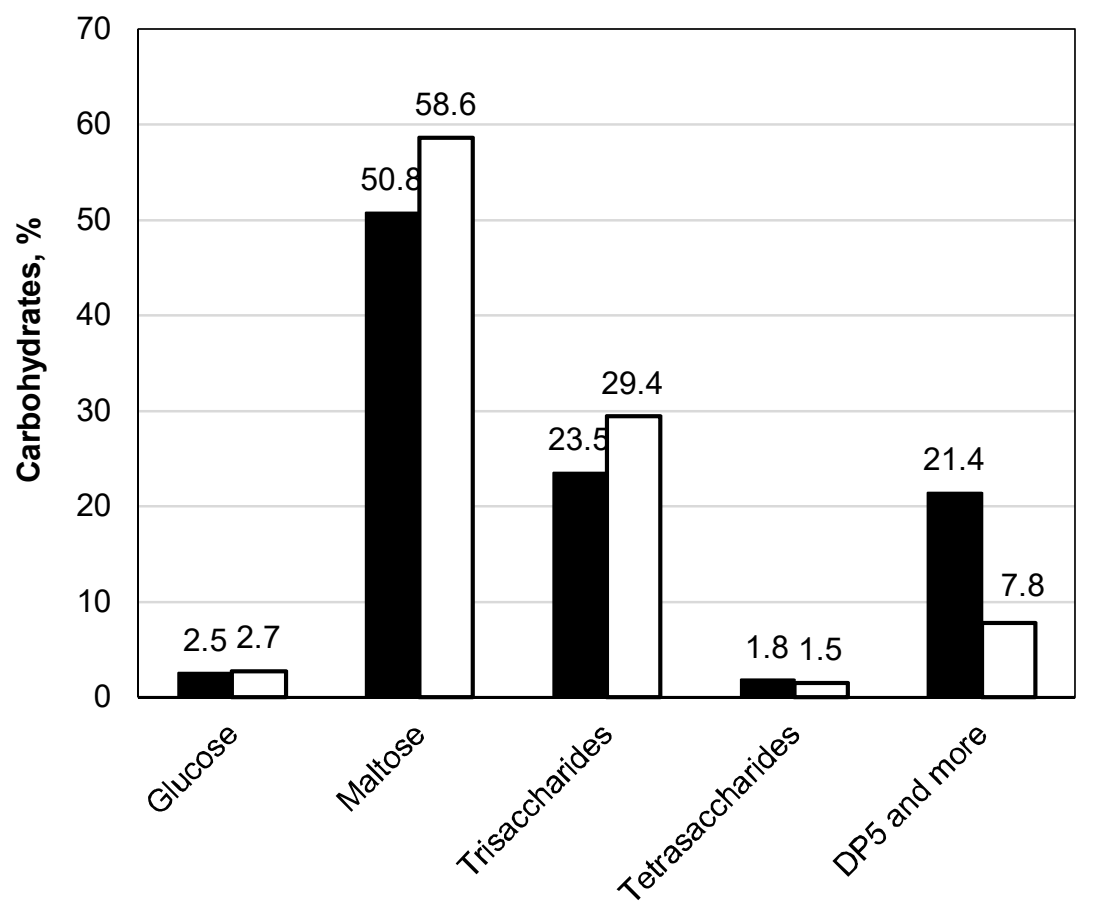

- $\beta$-amylase $\quad \square \beta$-amylase + pullulanase

Figure 5. Carbohydrate composition of maltose syrups obtained under optimal conditions and amounts of added saccharifying enzyme preparations:

$\beta$-amylase (control sample) and a complex of $\beta$-amylase and pullulanase

— Ukrainian Food Journal. 2021. Volume 10. Issue 4- 771 
These data make it possible to compare the carbohydrate composition of maltose syrups obtained using different saccharifying enzyme preparations: $\beta$-amylase (control sample) and mixture of $\beta$-amylase and pullulanase.

The results of chromatographic analysis allow to compare the carbohydrate composition of maltose hydrolysates obtained at the optimal dosage of the complex of enzyme preparations of $\beta$-amylase and pullulanase, with the control sample, in which saccharification occurred only with maltogenic enzyme preparation of $\beta$-amylase (Table 1). Figure 5 shows that the composition of starch hydrolysates after saccharification differs significantly depending on the combinations of saccharifying enzyme preparations. The introduction of pullulanase makes it possible to obtain syrups with a higher content of maltose $(58.6 \%$, compared with $50.8 \%$ in the absence of pullulanase). The accumulation of maltose occurs due to the rupture of $\alpha-1,6$ glucoside bonds in amylopectin chains, which are not affected by the enzyme preparation of $\beta$-amylase (EP 0294093 A2). The hydrolysates obtained using pullulanase have a lower content of $\beta$-limiting dextrins ( $7.8 \%$, compared with $21.4 \%$ in the absence of pullulanase). These dextrins are a source of additional maltose accumulation, as the substrate becomes available for $\beta$-amylase action in the absence of branching (Baks et al., 2008; Lin et al., 2013).

Based on the research results, the optimal parameters of the saccharification process of liquefied starch with a complex of enzyme preparations of $\beta$-amylase and pullulanase were determined. Using a complex of enzyme preparations it is possible to obtain maltose syrups with a maltose content of $60-62 \%$ and a DE value of $40-42 \%$ (Figure 3 and Table 1).

\section{Conclusion}

The kinetics of the process of enzymatic saccharification of starch hydrolysates depending on the obtained values of dextrose equivalent after liquefaction has been studied. It has been established that the highest value of dextrose equivalent in the process of saccharification to maltose is achieved at the optimal degree of liquefaction of the starch suspension, which corresponds to the value of glucose equivalent of $10-15 \%$.

The kinetics of the process of enzymatic saccharification of liquefied starch by a complex of enzymatic preparations of $\beta$-amylase and pullulanase has been examined. It has been found out that these enzyme preparations are best used in quantities of 0.03 units SA/g DS and 0.0006 units PA/g DS of starch, respectively. It has been determined that with the 24 hours' duration of saccharification the content of maltose in the hydrolysates reaches 60 $62 \%$ by weight of RS, with the content of glucose being insignificant (about $2.7 \%$ by weight of RS). Low glucose is a key indicator of the quality of syrups in the production of caramel and many other foods.

\section{References}

Ahmad R.A., Rizwana N., Manas N.H.A., Azelee N.I.W. (2019), Bioconversion of starch to maltooligosaccharides (MOS) by the reaction of maltogenic amylase, Jurnal Teknologi, 82(1), pp. 99-101.

Baks T., Kappen F.H.J., Janssena A.E.M., Booma R.M. (2008), Towards an optimal process for gelatinisation and hydrolysis of highly concentrated starch-water mixtures with alpha-amylase from B. licheniformis, Journal of Cereal Science, 47(2), pp. 214-225. 
Gangadharan D., Nampoothiri K.M., Sivaramakrishnan S., Pandey A. (2009), Immobilized bacterial $\alpha$-amylase for effective hydrolysis of raw and soluble starch, Food Research International, 42(4), pp. 436-442, DOI: 10.1016/j. foodres.2009.02.008.

Gebremariam, M.M., Zarnkow, M., Becker, T. (2013), Effect of drying temperature and time on alpha-amylase, beta-amylase, limit dextrinase activities and dimethyl sulphide level of teff (Eragrostis tef) malt, Food Bioprocess Technology, 6, pp. 3462-3472.

Iskakova J., Smanalieva J., Kulmyrzaev A., Fischer P., Methner F.J. (2017), Comparison of rheological and colorimetric measurements to determine $\alpha$-amylase activity for malt used for the beverage Bozo, International Journal of Food Properties, 20(9), pp. 2060 2070.

Ivanov A V., Shevchenko O., Marynin A., Stabnikov V., Gubenia O., Stabnikova O., Shevchenko., Gavva O., Saliuk A. Trends and expected benefits of the breaking edge food technologies in 2021-2030. Ukrainian Food Journal, 2021, 10(1), 7-36.

Lin Q., Xiao H., Liu G.Q., Liu Z., Li L., Yu F. (2013), Production of maltose syrup by enzymatic conversion of rice starch, Food and Bioprocess Technology, 6, pp. 242-248.

Manisha N.C., Dipali K.S., Rohini B.K., Tajeswini S.M., Pooja P.S., Kirti B.J., Rajeshwari V.R. (2016), Extraction and partial purification and kinetic study of beta amylase from sweet potato, Journal of Global Biosciences, 5(4), pp. 3892-3901.

Manso S., Aguado A. (2017), A review of sample preparation and its influence on $\mathrm{pH}$ determination in concrete samples, Materiales de Construcción, 67(325), pp. 1-9.

Meile K., Zhurinsh A., Briede L., Viksna A. (2018), Investigation of the sugar content in wood hydrolysates with iodometric titration and UPLC-ELSD, Agronomy Research, 16(1), pp. 167-175.

Nawaz H., Waheed R., Nawaz M., Shahwar D. (2020), Physical and chemical modifications in starch structure and reactivity, DOI:10.5772/intechopen. 88870.

Nielsen S.S. (2010), Food Analysis, Food Science Texts Series, DOI 10.1007/978-1-44191478-1-6.

Porras M.A., Ramos F.D., Diaz M.S., Cubitto M.A., Villar M.A. (2018), Modeling the bioconversion of starch to $\mathrm{P}(\mathrm{HB}-\mathrm{co}-\mathrm{HV})$ optimized by experimental design using Bacillus megaterium BBST4 strain, Environmental Technology, 40(9), pp. 1185-1202, DOI: 10.1080/09593330.2017.1418436.

Radovanovic N., Davidivic S., Miljkovic M., Pavlovic M., Buntic P., Lazic V., Mihajlovski K. (2018), $\beta$-amylase production by a novel strain Paenibacillus chitinolyticus CKS1 using commercial and waste substrates, Journal on Processing and Energy in Agriculture, 22(1), pp. 18-22.

Rittenauer M., Gladis S., Gastl M., Becker T. (2021), Gelatinization or pasting? The impact of different temperature, Foods, 10, pp. 1-15.

Sabadash N.I., Hrabovska O.V. (2015), Doslidzhennia protsesu ztsukriuvannia rozridzhenoho krokhmaliu fermentnym preparatom $\beta$-amilazy, Naukovi pratsi NUKHT, 21(2), pp. 223-230.

Saini R., Saini H.S., Dahiya A. (2017), Amylases: characteristics and industrial applications, Journal of Pharmacognosy and Phytochemistry, 6(4), pp. 1865-1871.

Souza I.A., Orsi D.S., Gomes A.J., Lunardi C.N. (2019), Enzymatic hydrolysis of starch into sugars is influenced by microgel assembly, Biotechnology Reports, 22, pp. 1-10.

Trisnaputri A.C., Usman N.R., Muhammad A., Mustawa M.A., Jaya M.A. (2018), Production Banana Glucose Syrup with the $\alpha$-Amylase Supplementation, International Journal of Applied Biology, 2(1), pp. 61-65.

Yadav P., Majumder C.B (2017), Production of glucose syrup by the hydrolysis of starch made from rotten potato, Journal of Integrated Science \& Technology, 5(1), pp. 19-22. 